\title{
Milking Hygiene and Handling Practices among Smallholder Dairy Farmers in Zanzibar
}

\author{
R. Andrew, T. Chusi, and G. P. Mwembezi
}

\section{ABSTRACT}

The livestock farming especially dairy industry is among the important components of the livestock sector in Zanzibar in terms source of animal protein, income, and employment. The present study was meant to investigate milking hygiene and handling practices among smallholder dairy farmers in Zanzibar. Cross-sectional study was conducted whereby a structured questionnaire was addressed to 359 dairy cattle farmers. The assessment of milking hygiene and handling practices among smallholder dairy farmers on were analyzed and then judged based on the selected indicators of good dairy farming practices of FAO and International Dairy Federation (IDF) and IDF, (FAO, 2011) and Zanzibar Food and Drug Board standard. The results revealed low milking hygiene and good handling practices. In addition, based on the Zanzibar Food and Drug Board' standards, farmers comply lowly with milk quality standards and food safety regulations. It was also found that farmers, traders and processors practised milking hygiene and handling measures like hand washing, udder and utensils cleaning milking boiling and packaging. However, key un-hygiene practices include the use of plastic containers, untreated water, and lack of teat dipping. It is recommended that, for safe and quality milk availability, farmers must be equipped with knowledge and skills on good milking hygiene and handling practices. There is a need to improve farmers' knowledge and implement hygienic milking practices in the milk production process to meet required milk quality and food safety standards. In addition, awareness creation on the importance of good milking and handling practices will create behavioural change and lead to an improvement in milk quality in Zanzibar.

Keywords: Milking hygiene, handling practices, safety, dairy products, dairy farmers, Zanzibar.

\section{INTRODUCTION}

Dairy is a growing and important component of the livestock sector in Zanzibar is very important in the provision of animal protein, income, and employment. Dairy is a complex mixture of macro and micro-nutrients and a rich source of fats, proteins, carbohydrates, minerals, and vitamins such as calcium, vitamin B12, and riboflavin [1]. It is estimated that the sector is very important to improve the living standards of the people and contributing towards reduction of poverty through improved nutrition, arising from consumption of milk and incomes raised from sale of milk and milk products [2]. Accordingly, the sector contributes up to $34 \%$ of the agricultural GDP and $4 \%$ of the overall national economy of Zanzibar [3] with annual growth projected at 3\% (Revolutionary Government of Zanzibar [4]. Albeit, its contribution, the average number of dairy cattle per household is about one cow [5]. The sector is characterized by low production and reproduction with capacity of feeding local requirements at $60 \%$ of the local of 7.3 million litres annually excluding the increasing demand for milk and milk products to service the tourist industry and for production of other related milk products such as cheese, yoghurt, ghee, flavored and UHT milk [6].
Submitted : November 29, 2021

Published : December 20, 2021

ISSN: $2684-1827$

DOI: $10.24018 /$ ejfood.2021.3.6.422

R. Andrew *

Department of Rural Development and Regional Planning, Institute of Rural Development Planning, Dodoma Tanzania.

(e-mail: randrew@irdp.ac.tz)

T. Chusi

Department of Development Finance and Management Studies, Institute of Rural Development Planning, Dodoma Tanzania.

G. P. Mwembezi

Department of Development Finance and Management Studies, Institute of Rural Development Planning, Dodoma Tanzania.

*Corresponding Author
In terms of nutrition status, the low productivity of the livestock sector is one of the major reasons why only small amounts of animal sources of food are available for human consumption in Sub-Saharan Africa [3]. In recent years the government started implementing the Agricultural Sector Development Programme-Livestock (ASDP-L)-Zanzibar Sub-Programmes for improving dairy sector in the isles. The essence of investing in this project was meant for improving productivity to reduce poverty. According to [7], agriculture has remained the main source of economic development and poverty reduction in Africa. With this regard, the main objective of ASDP-L was to increase the use of inputs and services in order to increase the output quantity and value per input. In dairy production systems proper investment in the form of breeds of cattle, feeds and feeding systems coupled with proper marketing systems were promoted as the key prerequisites for intensification.

In most developing countries, important technical, economic, and cultural constraints create suboptimal conditions for the hygienic production of milk [8]. In practice, scholars e.g., [9] have already identified various causes of Various factors ranging from pre-milking conditions (e.g., the health status of the lactating animals) to post-milking conditions (e.g., improper handling, storage, and processing) 
are responsible for low microbiological quality and safety of milk and milk products. Standard Operation Protocols (SOPs) require dairy producers to maintain the safety and quality of their raw milk to satisfy the highest expectations of the food industry and consumers [10]. Generally, dairy production takes place under very different circumstances which if not carefully considered results in poor quality and unhygienic. However, the development of sustainable production systems that produce safe food, enhance the environment, protect animal welfare, and improve dairy farmers' economic viability has remained the challenge in food systems [11], [12]. According to [13], smallholder farmers are required to produce milk that meets food safety and standards to take advantage of this growing demand for milk and dairy products. It is a matter of fact that milk is nutritious for people as well as for bacteria, highly perishable and prone to contamination [14]. It is well documented that unhygienic dairy handling has a potential negative impact on both farmers and consumers. Poor milk handling leads to diseases in both humans and cattle themselves. According to [15], key health challenges include food-borne diseases, food poisoning and zoonosis risk by raw milk and fresh dairy products. In addition, poor hygiene milking and handling practices could result in microbial milk contamination, pathogens dissemination, and udder contamination may occur at milking time between cows, hands of milkier man and milk machines from others [10]. Specifically, milk-borne pathogenic bacteria may result in serious diseases like Staphylococcus aureus, Salmonella spp., Listeria monocytogenes, Escherichia coli O157: H7 and Campylobacter are the main microbiological hazards associated with raw milk consumption [16].

In Tanzania, milk production, processing and chain organization have been evolving with potential for increasing production and productivity and chain effectiveness to meet consumer demands [17]. However, like in any Sub Saharan Africa, milk quality and safety in Tanzania consumers' health and nutrition suffer from food-borne diseases, food poisoning, and zoonosis risk by raw milk and fresh dairy products has remained a concern. The presence of microbial pathogens and other hazards in the informal market in Tanzania is high, yet the risk to human health is mostly unknown [18], [19]. According to [20], microbial residues in animal source food in Tanzania are also caused by poor animal health delivery systems. Generally, information on dairy and products quality and safety in Tanzania is scarce. By using Google Scholar and other search engines it was revealed that only one research [20] analyzed the quality of raw cow milk among smallholder dairy farmers in Zanzibar. However, that research mainly dwelt much on the end indicators i.e physicochemical parameters of raw cow milk and total viable count of microbes. In addition, taking into account Tanzania as a whole, still, empirical analysis on hygienic milking and practices is limited. Manyof studies [9], [18]-[25] targeted much on experimental and laboratorybased analyses while leaving aside roots causes of contamination, milking hygiene practices. This paper intended to assess milking hygiene and handling practices among small scale dairy farmers in Zanzibar.

\section{MATERIALS AND METHODS}

\section{A. Study Area}

The study was conducted in Pemba and Unguja islands in Tanzania. In each island, districts were selected based on the number of dairy cattle farmers. Selected districts include Kati, Magharibi B, Mjini, Kusini, Mkoani and Wete. These districts were chosen purposely for their different characteristics. Available data for the livestock sector in Zanzibar indicates that, by 2014, dairy cattle in Zanzibar was reared by about 2,422 households whereby in Kati district had 730 households rearing dairy cattle representing 30 percent of the total households followed by Magharibi district with $659(27.2 \%)$, Wete with $487(20.1 \%)$ and Chakechake with $248(10.2 \%)$ households. Kasikazini B, Kasikazini A, Micheweni, Mkoani and Kusini districts had very few less than $5 \%$ ) households engaged in the rearing of improved dairy cattle [26]. Two wards per district were randomly selected from the list of wards and a list of all producers, traders, and processors were involved. Traders and producers were randomly selected from sampling frames of the district, whereas all identified processors were included.

\section{B. Research Design}

This study applied cross-sectional research design whereby Focus Group Discussions (FGDs) and individual interviews were used to collect data used to investigate smallholder dairy farmers' hygienic milking and handling practices among smallholder dairy farmers in Zanzibar. Accordingly, the design provides a snapshot of the characteristics of the study subjects in a single time point and an investigator measures the outcomes and the exposures in the study subjects simultaneously [27], [28]. A crosssectional survey collects data to make inferences about a population of interest (universe) at one point in time. Crosssectional surveys have been described as snapshots of the populations about which they gather data. Cross-sectional surveys may be repeated periodically; however, in a repeated cross-sectional survey, respondents to the survey at one point in time are not intentionally sampled again, although a respondent to one administration of the survey could be randomly selected for a subsequent one [29]. Cross-sectional surveys can thus be contrasted with panel surveys, for which the individual respondents are followed over time. Panel surveys usually are conducted to measure a change in the population being studied.

\section{Focus Group Discussions (FGD)}

FGDs method was applied to collect qualitative data whereby smallholder dairy farmers were purposely selected to participate in FGDs. Selection process was made according to [30] whereby several criteria were considered. Each FGD consisted of between 6 and 9 participants conducted as either male or female and mixed groups. FGDs were conducted using a semi-structured interview guide with open-ended questions and were facilitated by a moderator, with a notetaker in the local languages and the national languages Kiswahili and English. FGDs explored farmers' hygienic milking and handling practices among smallholder dairy farmers in Zanzibar. Participants were asked to explain issues related to milking parlour cleanliness, hand, and udder cleaning, milking and storage containers, cleaning of milk 
containers, cow's vaccination and treatment and discarding milk from sick or treated cows.

\section{Survey}

The survey questionnaire had open and closed-ended questions and was based on Sustainable Agriculture Initiative [10] and recommended [31] indicators of hygiene milking and handling practices. We explored milking hygiene and quality practices as recommended [10] and [31], to identify good milk quality hygiene and safety practices. Key indicators include: (i) washing of udder before milking (ii) washing hands before milking (iii) cleaning of milking area, and (iv) containers used for milking and storage (aluminum/metal or plastic). Farmers' observation of withdrawal period for milk from sick and treated cows was identified as an indicator for the prevention of antibiotics residues [31]. About 259 dairy cattle farmers participated in the survey. on other hand, the questionnaire captured respondents' general information, e.g., district of residence, the gender of household head, education level, farming experience, gender and age of milker, farmer groups membership, herd size, choice of milk marketing channel, milk price, amount of milk sold, amount of milk consumed at home, access to water and access animal health.

\section{E. Data Analysis}

Descriptive analysis was also applied to describe the basic features such as trends of the data provided in this study, by providing the summary about the measures together with simple graphic analysis for quantitative data which was distinguished the community perception and sober houses example a table of means was used to show the important differences of groups and a crosstab or two-way tabulation were used to show the proportions of units with distinct values for each of two variables. The analyses for this study mainly applied content analysis. [32] define content analysis as a research method for the subjective interpretation of the content of text data through the systematic classification process of coding and identifying themes or patterns. In addition, the content analysis goes beyond merely counting words to examining language intensely for the purpose of classifying large amounts of text into an efficient number of categories that represent similar meanings [33].

\section{RESULTS AND DISCUSSIONS}

\section{A. Milking Hygiene, Milk Storage and Milk Safety}

The overall results of the survey evaluating farmers' milking hygiene and handling practices are presented in Table I. The results (Table I) indicate that somehow, half of farmers use all chemicals and veterinary medicines as prescribed to prevent the occurrence of chemical residues in milk. About $52 \%$ of farmers were aware of the use of chemical and veterinary medicines. According to directions, calculate dosages carefully and observe the withholding period. The majority of farmers $(63 \%)$ use chemicals and veterinary medicines strategically with the aim of reducing the use of these inputs where appropriate. Furthermore, $67 \%$ of farmers use veterinary medicines as prescribed by veterinarians and observe withholding periods. The situation was found possible because of Community Animal Health Workers (CAHWs) who were trained to support farmers in treating cows since in Zanzibar; there are very few veterinary officers. Animal health is very crucial for production and marketing of quality milk. 'In the islands, there are very few veterinary officers to offer services. For example, Pemba Island has only one veterinary officer with Bachelor of Veterinary Medicine. The Revolutionary Government of Zanzibar in collaboration with development partners (eg. Heifer International Tanzania, IFAD) trained Community Animal Health Workers (CAHWs) to provide animal health services in Shehias' one of the government officials explained during a key informant interview. Unfortunately, only about $43 \%$ of dairy cattle farmers store chemicals and veterinary medicines securely, respect expiry date and dispose of them responsibly. The results are in conformity with findings by [34] who found that in India, the occurrence of antibiotic- contaminated was frequently being reported. In addition, [35] reported that farmers administered the drugs without getting advice from animal health professionals and by using improper and simple dose estimations based on age and body weight of the animals. With this regard, such a situation might have a similar trend in developing countries.

The second category for principles of good practices assessed was the extent farmers do ensure that milking routines do not injure cows or introduce contamination to milk. The results revealed the adoption of milk quality and safety practices by smallholder farmers. Farmers widely adopted animal health practices such as deworming, vaccination and self-treating cows with purchased drugs. Results (Table I) show that the majority of farmers, $86 \%$, ensure appropriate udder preparation for milking. Moreover, only $47 \%$ of farmers use best practices, milking techniques are applied at all times while $56 \%$ separate milk when required, from sick or treated animals. In addition, $66 \%$ of farmers ensure that the milking equipment is correctly installed and maintained. However, it was revealed that none of the farmers used aluminum equipment rather all used plastic materials. The results are in accordance with the results by [36] who found that a minority of farmers adopted animal health measures and hygienic measures such as hand washing and udder cleaning. Moreover, unhygienic milking environments, the use of plastic containers, the use of untreated water, and the lack of teat dipping compromised milk quality and safety. Currently, milk production, handling and consumption could expose actors along the dairy value chain to health risks. The adoption of milk quality and food safety practices was influenced by farmers' knowledge, socioeconomic characteristics, and choice of marketing channel.

Concerning carrying out milking activities under hygienic conditions was assessed based on four parameters. Table I shows that a majority of farmers, $74 \%$, were found ensuring that the housing environment allows the animals to keep as clean as possible while about $68 \%$ of farmers do clean and dry areas in which cows lie down to promote udder cleanliness. Furthermore, the results assessed to what extent the milking area is kept clean and whether milkers follow hygiene rules. The majority of farmers $(84 \%)$ ensure that the milking area is kept clean while $76 \%$ reported striving to follow hygiene rules. Keys rules identified include washing their hands before milking, using a reusable towel to dry their hands and cleaning udders. 
Principle four was meant to assess milk handling after milking activities. The results revealed that only $54 \%$ of farmers ensured milk is cooled to the specified temperature and/or delivered to collection centres or sold to traders. All farmers cooled milk using local methods, putting milk containers in cool water and very few had freezers. Our findings are also consistent with studies in Mali by [37] and in Kenya by [38], where most farmers, milk traders and bars held milk at ambient temperatures due to lack of cooling systems. Accordingly, milk cooling is not a common practice along the dairy chain, monitoring of milk safety and quality parameters is limited, particularly for pathogenic bacteria, indicating a risk for milk safety [9]. Further, at least about $52 \%$ of respondents were able to ensure that milking equipment is sanitized with potable water or water free of pathogens. However, during FGDs it was discussed that very few farmers used boiled water. The results concur with [39] who found that in Kenya cleaning of milking equipment is practiced by slightly above half of the respondents.

\section{B. Milk Handling and Processing Environment at Local Level}

The study aimed at assessing milk handling and processing environment at local level to identify practices with regards to hygiene that implicate quality. The findings revealed that the milking processing environment was not conducive. Plate 1 indicates the processing environment of one of the prominent processing local plants in Zanzibar. Moreover, plates 2 and 3 indicate packed milk and milk boiling containers, which are equally not in conformity with hygiene and safety requirements of milk processing and packaging. Hygienic milk production, handling and processing are key issues in promoting livestock production. This is consistent with other studies where a poor environment at local milk processing was revealed [9], [13], [40]. However, setting and enforcing milk quality and safety standards is mainly targeted at the formal dairy chain, with no enforcement in the informal dairy chain, although only a small fraction of the total milk supply is accounted for by the formal chain. Overall, the organization of control activities and enforcement of requirements on dairy quality is not uniform across the chains [9]. Better hygiene can significantly improve the health of producers as well as consumers, but in rural areas in Afghanistan and Pakistan there has been little or no effort to promote these simple technologies.

TABLE I: MiLking Hygiene, MiLK StoRAge AND MiLK SAFETY

\begin{tabular}{|c|c|c|}
\hline Principle & Recommended Practices & $\begin{array}{l}\text { Compliance } \\
\text { among } \\
\text { farmers }(\%)\end{array}$ \\
\hline \multirow{4}{*}{$\begin{array}{l}\text { Use all chemicals and veterinary } \\
\text { medicines as prescribed to prevent } \\
\text { occurrence of chemical residues in } \\
\text { milk. }\end{array}$} & $\begin{array}{l}\text { Use chemical and veterinary medicines according to directions, calculate dosages carefully } \\
\text { and observe withholding period. }\end{array}$ & 52 \\
\hline & $\begin{array}{l}\text { Use chemicals and veterinary medicines strategically with the aim of reducing the use of } \\
\text { these inputs where appropriate. }\end{array}$ & 63 \\
\hline & Use veterinary medicines as prescribed by veterinarians and observe withhold periods. & 67 \\
\hline & $\begin{array}{l}\text { Store chemicals and veterinary medicines securely, respect expiry date and dispose of them } \\
\text { responsibly }\end{array}$ & 43 \\
\hline \multirow{4}{*}{$\begin{array}{l}\text { Ensure that milking routines do } \\
\text { not injure cows or introduce } \\
\text { contamination to milk. }\end{array}$} & Ensure appropriate udder preparation for milking. & 86 \\
\hline & Ensure best practice milking techniques are applied at all times. & 47 \\
\hline & Separate milk when required, from sick or treated animals. & 56 \\
\hline & Ensure that the milking equipment is correctly installed and maintained. & 66 \\
\hline \multirow{4}{*}{$\begin{array}{l}\text { Carry out milking activities under } \\
\text { hygienic conditions }\end{array}$} & Ensure that the housing environment allows the animals to keep as clean as possible. & 42 \\
\hline & Cows should have a clean dry area in which to lie down to promote udder cleanliness & 68 \\
\hline & Ensure that the milking area is kept clean. & 84 \\
\hline & Ensure that the milkers follow hygiene rules. & 76 \\
\hline \multirow[t]{6}{*}{$\begin{array}{l}\text { Handle milk properly after } \\
\text { milking activities. }\end{array}$} & $\begin{array}{l}\text { Ensure that the milk is cooled to the specified temperature and/or delivered to a processing } \\
\text { plant in a specified time. }\end{array}$ & 54 \\
\hline & Ensure that milking equipment is sanitized with potable water or water free of pathogens. & 52 \\
\hline & Ensure that the milk storage area is clean and tidy. & 69 \\
\hline & $\begin{array}{l}\text { Ensure that milk storage equipment is adequate to cool and hold milk at the specified } \\
\text { temperature. }\end{array}$ & 38 \\
\hline & Keep the access for bulk milk collection unobstructed & 25 \\
\hline & Use of plastic container & 100 \\
\hline
\end{tabular}

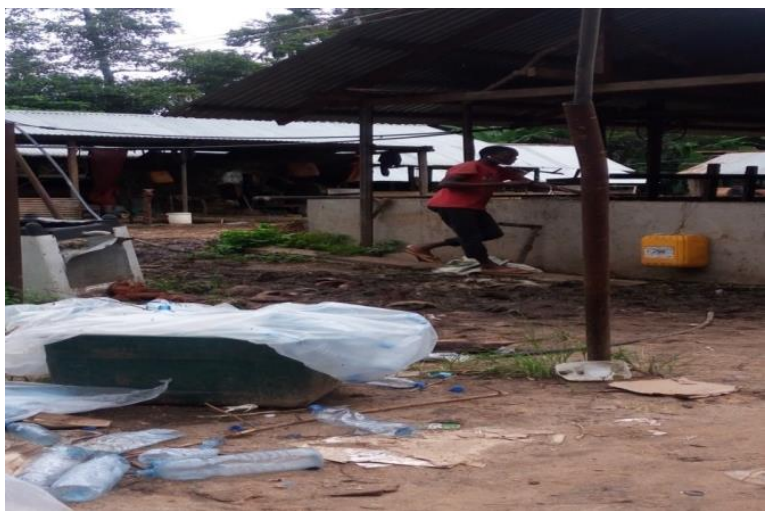

Plate 1. Appearance of the environment of one of the dairy processing plants in Zanzibar.

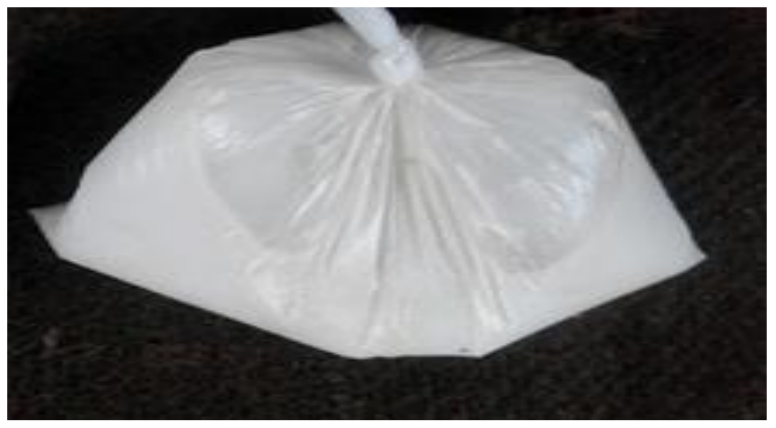

Plate 2. Milk Packed using inappropriate material. 


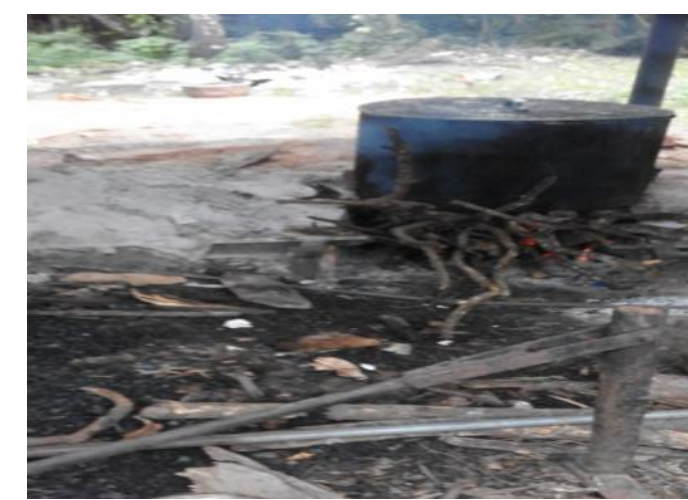

Plate 3. Milk boiling at processing unit

\section{Farmers' Compliance with Milk Safety and Quality Guidelines}

The study also reviewed the experiences, practices, and other effective or sustainable approaches farmers in complying with the milk safety and quality guideline along the value chain. Milk-safety problems in the country include adulteration (water and other substances), prevalence of the antimicrobial residues, drugs and heavy metals in milk and zoonotic diseases. The wide prevalence of these problems can partly be attributed to the lack of quality assurance systems among the informal and formal operators involved in the value chain. Along the milk value chain in Zanzibar, almost all actors in the value chain do not perform their functions according to the regulations. Milk safety is required through food safety standards and regulations for milk and dairy products, mainly the Dairy Industry Act (CAP 336) and the Public Health Act (CAP 242) [41]. Efforts are being made to blend standards across the East Africa region [43].

Agricultural Sector Policy, 2003 is used to guide agricultural sector operations in Zanzibar. Section 2.3 of the policy is specific to Livestock while section 2.3.3 elaborates the objective for Dairy Development which is to achieve selfsufficiency in the production of milk and dairy products. In a nutshell, the policy environment is conducive to improve the dairy sector in the islands. On the other hand, the Zanzibar Food, Drugs and Cosmetic Act No. 2 of 2006 [42] and Zanzibar Milk regulation of 2011[41] are the main dairy industry regulators. The Act and Milk regulation, both stipulate all issues along milk value chain and the following are statements explained in these documents:

i) Standards;

ii) Adulteration and misbranding;

iii) Production of milk;

iv) Pasteurizing plants approval;

v) Manufacture or processing of milk products.

Along the milk value chain in Zanzibar, almost all actors in the value chain do not perform their functions according to the regulations. The dysfunction, inefficiency which is apparent in the industry is being caused by among other things lack of clear understanding of the regulations and act among actors, poor coordination and implementation of the guidelines, overlap of regulatory functions, political system and revenue collection strategies with departments of the government and dishonesty among actors. There are set conditions for safe milk production and marketing meant for each actor to operate accordingly. Taking just one element; Standards: Part III, Section 10 states that no person shall sell, offer for sale, or deliver anywhere in Zanzibar milk that has not been pasteurized in accordance with these Regulations. Section 11 (1) 11.(1) Milk obtained from a cow within 15 days before and 5 days after calving shall not be sold or delivered for human consumption. (2) Milk shall be free from coloring matter, preservative, or anything foreign to natural milk and shall contain not less than 3.25 percent of milk fat and not less than 8 percent of solids other than fat.12 (1) Milk obtained from a cow within 72 hours after the cow has been treated with an antibiotic for any purpose, shall not be sold or delivered for human consumption. During FGDs, it was revealed that farmers are aware that they are not supposed to milk the cow after treatment but sometimes they treat and milk in the same day to compensate the cost incurred. The dysfunction, inefficiency which is apparent in the industry is being caused by among other things lack of clear understanding of the regulations and act among actors, poor coordination and implementation of the guidelines, overlap of regulatory functions, political system and revenue collection strategies with departments of the government and dishonesty among actors. Milk obtained from a cow within 72 hours after the cow has been treated with an antibiotic for any purpose, shall not be sold or delivered for human consumption. Further, farmers and traders refill milk in water bottles (drops) for sale, the action which is contrary to Zanzibar milk regulations. During the field work, observation revealed that the milking handling and trading environment in Zanzibar is very unhygienic as it can be seen in the plated below.

Zanzibar Food and Drug Board has identified just two informal selling points found at Amani and Mahurubi areas where many milk traders allocate milk for sale, "We know that milk in the market is not safe for consumers but we cannot prohibit milk business because of political issues as well as traders are levied by the authorities and hence the business is seen as legalized in that condition. Also, the Milk Act and Milk regulations guide us to inspect milk in registered premises so we cannot reinforce them once milk is being sold in unregistered premises". One of the officers explained. "We are striving to recognize small enterprises engaged in milk processing, we made a survey and found that all processors have not met the requirements as per our regulation and hence we have not registered any processor this was explained by the registrar and evaluator of food of the board. Further, the milk inspector explained that "in each time we inspect milk at Amani and Mahurubi centres, some samples are found with antibiotic residues indicating that farmers milk cows within antibiotic incubation period". Although the responsible body is striving to control the quality and safety of milk produced, its coverage is limited as it inspects at just two points in Unguja while in Pemba no inspection is done.

\section{CONCLUSION AND RECOMMENDATIONS}

Based on the main findings of the present study it can be concluded that improvement of milk safety can be achieved through good management practices by dairy farmers, market incentives, and increased efforts of various stakeholders and the adoption of best practices. In this regard, a coordinated action involving all stakeholders is needed to implement 
hygienic milking and handling practices among smallholder dairy farmers and appropriate regulation while supporting and building capacity of smallholder dairy producers to minimize risks associated with milk production. Investment and promotion of proper milk handling utensils must be considered for increased milk quality. Farmers should be facilitated to adopt good animal husbandry practices in order to improve milk yields and profit. To achieve this, Zanzibar Food, Drug, and cosmetic Board (ZFDB) must cooperate with key stakeholders in the dairy sector to support farmers, and also it should undertake inspection for milk quality assurance.

\section{CONFLICT OF INTEREST}

Authors declare that they do not have any conflict of interest.

\section{REFERENCES}

[1] Dugum B, Janssens GPJ. Assessment of dairy farmers' hygienic milking practices and awareness of cattle and milk-borne zoonoses in Jimma, Ethiopia. Food Science and Quality Management. 2015; 45 114-121. https://www.i iste.org/Journals/index .php/FSQM/article/v iew/27010

[2] Faria J. Production volume of dairy products in Zanzibar from 2016 to 2020(in 1,000 liters). 2021. https://www.statista.com/statisti cs/1185025.

[3] IFAD. Agricultural Sector Development Programme - Livestock Zanzibar. Supervision report. https://operations.ifad.org /documents/654016/598b6295-b6ca-401c-9205-4624559ce3ae, 2016.

[4] Revolutionary Government of Zanzibar (RGoZ). Zanzibar Agricultural Sector Policy of 2003.

http://www. zanzibarassembly.go.tz/act_2006/act_2.pdf, 2011.

[5] RGoZ. Zanzibar Food Security and Nutrition Analysis Report. Integrated Food Security Phase Classification. Zanzibar Food Security and Nutrition Monitoring - Ipc Technical Working Group (Twg). https://reliefweb.int/sites/reliefweb.int/files/ resources/1, 2016.

[6] RGoZ. National sample census of agriculture 2007/2008; volume VI: livestock sector - Zanzibar report. Zanzibar: Office of Chief Government Statisticians. http://www.nbs.go. tz/nbstz/index, 2012.

[7] Pretty J, Toulmin C, Williams S. Sustainable intensification in African agriculture. IJAS. 2011;9 (1): 5-24. https://doi.org/ 10.3763/ij as.201 0.0583 .

[8] Ledo J, Kasper A., Hettinga, JB, Pieternel K, Luning, A. Implications of differences in safety and hygiene control practices for microbial safety and aflatoxin M1 in an emerging dairy chain: The case of Tanzania. JFC, 2020.;118(1). https://doi.org/10.10 16/j.foodcont.202 0.107453 .

[9] de la Fuente M.A., and Juárez M. Milk and dairy products. 2015, pp 645-668 in Handbook of Mineral Elements in Food. M. dela Guardia and S. Garrigues, ed. John Wiley and Sons Ltd., West Sussex, UK.

[10] Sustainable Agriculture Initiative (SAI). Principles and Practices for Sustainable Dairy Farming (version 2015), (2015). https://saiplatform.org/uploads/.

[11] Morgan, T. Good Dairy Farming Practices related to Primary Production of Milk and Farm Management. Bulletin of International Dairy Federation, 2007. https://fil-idf.org.

[12] Amenu, K., Wieland, B., Szonyi, B., and Grace, D. Milk handling practices and consumption behavior among Borana pastoralists in southern Ethiopia. JHP, 2019;38(1): 6-15. https://doi.org/10.11 86/s41043-019-0163-7.

[13] Lemma DH, Mengistu A., KumaT, Kuma, B. Improving milk safety at farm-level in an intensive dairy production system: relevance to smallholder dairy producers. FQS, 2018;2(3):135-143. https://doi.org/10.1093/fqsafe /fyy009.

[14] Lindahl FJ., Deka RP, Assee R, Laparf L, Delia G. Hygiene knowledge, attitudes and practices among dairy value chain actors in Assam, north-east India and the impact of a training intervention. JIEE, 2018. 8(1): 1-10. https://doi.org/10.108 0/20008686.2018.1555 444.

[15] Velázquez-Ordoñez V, Valladares-Carranza B, Tenorio-Borroto E, Talavera-Rojas M, Varela-Guerrero JA, Acosta-Dibarrat J, Puigvert F, Grille L, Revello A G, Pareja L. Microbial Contamination in Milk
Quality and Health Risk of the Consumers of Raw Milk and Dairy Products. IntechOpen, 2019. DOI: 10.5772/intechopen.86182.

[16] Claeys W, Cardoen S, Daube G, De Block J, Dewettinck K, Dierick K. Raw or heated cow milk consumption: Review of risks and benefits. $J F C, 2013 ; 31: 251-262$ https://doi.org/10.1016/jfood cont.2012.09.035.

[17] Kurwijila L R, Bennett A. Dairy development institutions in East Africa: Lessons learned and options. 2011. Rome: https://edepot.wur.n1/334382.

[18] Caudell MA, Charoonsophonsak MV, Miller A, Lyimo B, Subbiah M., Buza J, Call, D R. Narrative risk messages increase uptake and sharing of health interventions in a hard-to-reach population: A pilot study to promote milk safety among Maasai pastoralists in Tanzania. Pastoralism: RPP, 2019;9(7): 1-12. https://doi.org/10.1186/s13570 019-0142-z.

[19] Shija, F. Assessment of Milk Handling Practices and Bacterial Contaminations along the Dairy Value Chain in Lushoto and Handeni Districts, Tanzania. 2013. https://core.ac.uk/dow nload/pdf/1 32683019.pdf.

[20] Gwandu SH, Nonga H E, Mdegela R H, Katakweba A S, Suleiman T S, Ryoba R. Assessment of Raw Cow Milk Quality in Smallholder Dairy Farms in Pemba Island Zanzibar, Tanzania. JVMI 2018. https://www.hindawi. com/journals/ vmi/2018/1031726/.

[21] Häsler B, Fornace K, Eltolth M, Rushton J. Rapid assessment of nutrition \& food safety risks in dairy value chains in Tanzania. 2013. https://core.ac.uk /download/pdf /132667174.pdf.

[22] Fornace, G.M and Mahmoud, K. E. (2018). Integrated food safety and nutrition assessments in the dairy cattle value chain in Tanzania. Global Food Security. https://ebrary.ifpri.org/digita 1/collection/p15738coll9/id/580.

[23] Kussaga JB, Luning PA, Tiisekwa B P M, Jacxsens L. Current performance of food safety management systems of dairy processing companies in Tanzania. 2014. https://doi.org/10.1111/14710307.12183.

[24] Schoder D, Maichin A, Lema B, Laffa J. Microbiological quality of milk in Tanzania: from Maasai stable to African consumer table. JFP 2013;76 (11):1908-15. doi: 10.4315/0362-028X.JFP-13-101. PMID: 24215695 .

[25] Schooman L, Swai, ES. Marketing, handling and physical quality of raw marketed milk in Tanga region of Tanzania. LRRD, 2011;23 (9) http://www.lrrd.org/lrrd23/9/s cho23191.htm.

[26] RGoZ. Zanzibar Food Security and Nutrition Analysis Report. Integrated Food Security Phase Classification. Zanzibar Food Security and Nutrition Monitoring - Ipc Technical Working Group (Twg). 2016 https://reliefweb.int/sites/reliefweb.int/files/ resources/1.

[27] Etminan M, Samii A. Pharmacoepidemiology: a review of pharmacoepidemiologic study designs. Pharmacotherapy: JHPDT, 2004;24(8):964-969. https://doi.org/10.1016/B978-0-12-812735$3.00602-6$

[28] Hulley SB, Cummings SR, Browner WS, Grady D, Newman TB. Designing Clinical Research (fourth ed.) 2013. Wolters Kluwer Health/Lippincott Williams \& Wilkins.

[29] Lavrakas PJ. Cross-Sectional Survey Design. In: Encyclopedia of Survey Research Methods. $2008 . \quad$ DOI: https://dx.doi.org/10.4135/9781412963947.n120.

[30] Krueger R.A. Designing and Conducting Focus Group Interviews 2002. https://www.eiu.edu/ihec/Krueger-FocusGroupInterviews.pdf.

[31] FAO. Cattle and small ruminant production systems in sub-Saharan Africa. A systematic review. 2013. pp 105.

[32] Hsieh H F, Shannon S E. Three Approaches to Qualitative Content Analysis. $Q H R, \quad 2005 ; 15(9): 1277-1288 . \quad$ doi:10.1177/104973 2305276687.

[33] Weber, R. P. Basic content analysis. 96 pp Beverly Hills, CA: Sage, 1990.

[34] Mutua F, Sharma G, Grace D, Bandyopadhyay S, Shome B, Lindahl J. A review of animal health and drug use practices in India, and their possible link to antimicrobial resistance. JARIC, 2020; 9 (1): 1-13. DOI - 10.1186/s13756-020-00760-3.

[35] Tufa T B, Gurmu F, Beyi A F, Hogeveen H, Beyene T.J, Ayana D, Woldemariyam FT, Hailemariam E, Gutema F D, Stegeman J A. Veterinary medicinal product usage among food animal producers and its health implications in Central Ethiopia. 2018. DOI https://doi.org/10.1186/s12917-018-1737-0.

[36] Nyokabi S, Luning A P, de Boer IJM, Korir L, Muunda E, Bebe B O, Lindahl J, Bett B, Oosting SJ. Milk quality and hygiene: Knowledge, attitudes and practices of smallholder dairy farmers in central Kenya. JFC, 2021;130:1-10. doi.org/10.1016/j.foodcont.2021.108303.

[37] Bonfoh B,Wasem A,Traore A, Fane A, Spillmann H, Simbé C. Microbiological quality of cows' milk taken at different intervals from 
the udder to the selling point in Bamako (Mali). JFC, 2003;14(7):495500. https://doi.org/10. 1016/S0956-7135(02)00109-3.

[38] Ndungu TW, Muliro PS, Omwamba M, Oosterwijk G, Jansen A. Quality control of raw milk in the smallholder collection and bulking enterprises in Nakuru and Nyandarua Counties, Kenya. AJFS, 2016; 10(5): 70-78. DOI: 10.5897/AJFS2015.1412.

[39] Wairimu E, Mburu J, Gachuiri CK, Ndambi A. Characterization of dairy innovations in selected milksheds in Kenya using a categorical principal component analysis. TAHP, 2021; 53 (1): 1-12. https://doi.org /10.1007/s11250-021-02596-4.

[40] Burke N, Zacharski K A, Southern M, Hogan P, Michael P, Ryan M C, Adley C C. The Dairy Industry: Process, Monitoring, Standards, and Quality. Intech Open Book Series. 2018 DOI: 10.5772/intechopen.80398.

[41] RGoZ. Milk Regulations of 2006. http://zfdb.go.tz/wpcontent/downloads/ regulations/Milk\%20regulations.pdf.

[42] Government of Zanzibar. The Zanzibar Food, Drugs and Cosmetics Act, No.2 of 2006. 2006. https://trade. Tanzania.go.tz/media/.

[43] FAO. The State of Food Insecurity in the World. The Multiple Dimensions of Food Security (Rome). 2013. http://www.fao.org/3/ai3434e.pdf. 